\title{
Rural Women's Health Problems In Khyber Pukhtun Khwa Of Pakistan
}

\author{
Amir Zada Asad \\ Sumera Farid \\ \& \\ Basharat Hussain \\ Department of Social Work \\ Peshawar University
}

\begin{abstract}
Pakistan is a third world country, with more than $60 \%$ rural population, confronted with a lot of social problems including poor health of the masses particularly women, illiteracy and low quality education, poverty, misgovernment and corruption at all levels, weak institutions and lack of good governance. Consequently, the public suffers due to all these problems. Women suffer more than men in all walks of life particularly education and health delivery services which are either not available to them or denied to them on state level. This article is based on an empirical study conducted in the North-West Pakistan known as Khyber Pukhtun Khwa (previously NWFP) to know about the rural women health problems of the poorest province of a poor country. Results shows that the province is not only poor, but also has the characteristic of large families, high fertility rate, a harsh culture towards women, non-availability of medical facilities making women in particular to resort to shrines and Mullahs for spiritual treatment and so on.
\end{abstract}

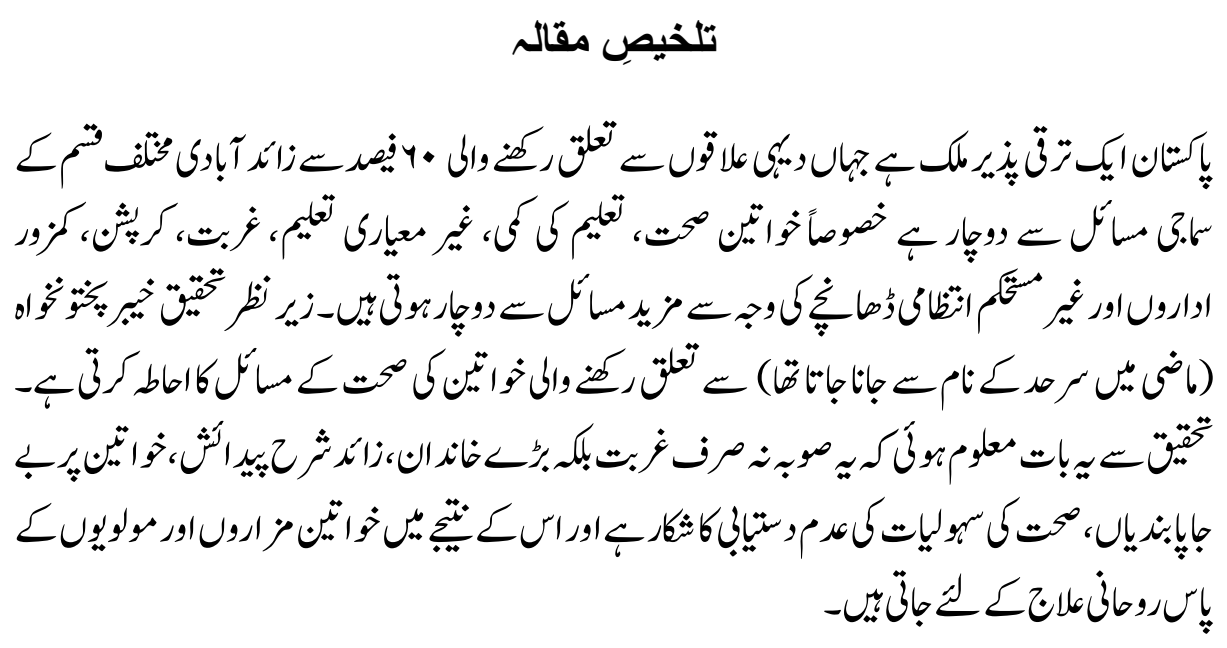

\section{Key Words}

Women, Pakistan, a third world country, misgovernment and corruption, inefficient medical institution and officials, poverty, delivery at home at the hands of Traditional Birth attendants (TBAs), the culture of Purdha (seclusion), the role of in-laws in women health issues. 


\section{Introduction}

Pakistan is one of the poorest nations in the globe and is an aid-dependent country. In Pakistan 73.6\% people earn less than US\$ 2 a day (Human Development Report, 2009, p, 209). There are wide gaps between the health delivery facilities among the rural and urban areas. Poverty is rampant, lack of medicines in the health institutions, services purchase power by common man, and lack of proper management are the major problems of health delivery system. These have resulted in the spread of preventable communicable diseases, malnutrition, and high child and maternal mortality rates (Federal Bureau of Statistics, 2009, p, 1).

A high official report states the health situation in Pakistan as:

"the most immediate health problems are... poor living conditions, poverty and low literacy rate with women being the worse affectees... vulnerable to various diseases...Malnutrition is a major public health problem that disproportionately affects women, girls, and infants" (Federal Bureau of Revenue, 2008-9, p, 169).

The most obvious reason of this situation is the poor economic conditions of the country. The dwindling economic conditions, mismanagement and corruption, lack of states' will and power to induce changes in the traditional health care system are too far dreams. In Pakistan we spend only $0.59 \%$ of the Gross Domestic Production on the health sector (Federal Bureau of Revenue, 2008-9, p, 171). Consequently, we have the most tenuous health delivery system with the availability of one doctor for over 1200 persons, a dentist for over 18000 persons, and one hospital bed for over 1500 person (Federal Bureau of Revenue, 2008-9, p, 171).

In Pakistan,

"We are losing three women per hour because of pregnancy associated complications. More than 30, 000 young women die every year... which gives a mortality rate of $340 / 100,000$ pregnancies. More than $80 \%$ women are delivered at home in the presence of unskilled birth attendants (Health of Women in Pakistan, Annual Report, 2009, p, 3)

Khyber Pukhtun Khwa (herein after KPK) is the third largest province of the country in term of population. It has an area of 74,521 sq. km. with an estimated population of 2, 13, 92,000 (2006 estimates) and population density of 287 is more than for all over the country with 197 for Pakistan. In education sector, KPK also lags behind. It has a literacy rate of $45 \%$ as compared to the $53 \%$ for Pakistan (Bureau of Statistics, Planning and Development Department, 2008, p, iv).

In terms of health it is again at disadvantage. The total no. of health institutions including hospitals, basic health Units, Rural Health Centers, Dispensaries and Maternal and Child 
Health Centers, leprosy and Tuberculosis (TB) centers, in the province is 1476 (Bureau of Statistics, Planning and Development Department, 2008, p, vi) for a population of over 20 million as compared to 12804 (Federal Bureau of Statistics, 2008, p, 22) for the whole of Pakistan. It is a matter of common observation that dispensaries and leprosy centers in the province especially in the rural area are of less or no benefit to the public as they are not only lacking with staff but also with medicines. Mostly, such dispensaries are run by the Chawkidars (security guards) or the orderlies and the Para-medical staff is always busy in their own private practices. Only hospitals and Basic Health Units (BHUs) are of some benefit to the public where at least qualified staffs are sometimes available.

This situation has far reaching negative impacts on the development of overall socioeconomic indicators particularly the health. This situation mars the development of establishing new health institutions, maintenance of already existing institutions, its impacts on the psycho-physical set up of the public and particularly of the females, lead to high morbidity rates. Women's extreme poor conditions, low socio-economic roles and status condition them to health hazards, leading to endless sufferings and many preventable deaths. In addition to this, the concentration of health services in the urban centers, have made it practically difficult if not impossible for women to avail these services.

\section{Method and Material}

This is a descriptive, exploratory \& explanatory study of cross- sectional character is based on field data collected during 2011-12. The main objective of the research is to find out the prevailing health problems of women in the province.

The secondary objectives will be,

1. To find out the socio-economic \& cultural factors responsible for poor health conditions of women.

2. To have an idea of the disease pattern among women in the province.

NWFP is administratively divided into seven divisions' i.e. Bannu, Kohat, D.I. Khan, Peshawar, Mardan, Malakand and Hazara division. The province is mostly rural only with the district capitals being urban. One district was selected from each division randomly giving a total of seven districts. The districts so selected were, Lower Dir, Mardan, Mansehra, Kark, Bannu, D.I. Khan and Peshawar Districts. Data from patients were obtained in the Out Patient Department (OPDs) of the category A or B Hospitals of these districts at the District Headquarters (DHQ) as mostly people prefer to go to the DHQs for treatment as very little or no facilities were available in the rural health institutions. Respondents were selected purposively and randomly. The purpose was the rural background of the respondents and randomization was made among the available 
population. From each OPD 20 patients were selected so for that a total of 140 sample size was obtained.

\section{Tools for Data Collection}

Keeping in view the nature of the study, and to collect reliable and authentic data, a semistructured Interview schedule was used to obtain both qualitative and quantitative data. The advantage of SSI schedule is that the interviewer can asks the major questions by rephrasing it, repeating it or reword it. $\mathrm{He} / \mathrm{she}$ is free to change their sequence and to probe more beyond the question (Nigel, 1993, p, 125). The interviewer can thus adapt the research instrument to the level of articulacy of the respondent, and handle it by responding to a query.

\section{Results}

Table 1

Age of Respondent

\begin{tabular}{|c|c|c|c|c|c|c|}
\hline $\begin{array}{c}\text { Age of the } \\
\text { woman }\end{array}$ & $\mathbf{1 1 - 2 0}$ & $\mathbf{2 1 - 3 0}$ & $\mathbf{3 1 - 4 0}$ & $\mathbf{4 1 - 5 0}$ & $\mathbf{5 1 +}$ & Total \\
\hline Frequency & $\begin{array}{c}19 \\
(13.6 \%)\end{array}$ & $\begin{array}{c}49 \\
(35 \%)\end{array}$ & $\begin{array}{c}40 \\
(28.6 \%)\end{array}$ & $\begin{array}{c}22 \\
(15.7 \%)\end{array}$ & $\begin{array}{c}10 \\
(7.14 \%)\end{array}$ & $\begin{array}{c}140 \\
(100 \%)\end{array}$ \\
\hline
\end{tabular}

This table shows the age of the respondents.19/140 ((13.6\%) \%) respondents were in the age group of 10-20. 49/140 (35\%)) respondents were in the age group of 21-30. 40/140 $(28.6 \%)$ respondents were in the age group of 31-40. 22/140 (15.7\%) respondents were in the age group of 41-50.10/140 (7.1\%) respondents were in the age group of $51+$

Table 2

Marital Status

\begin{tabular}{|l|c|c|c|c|c|c|}
\hline Age group & $\mathbf{1 1 - 2 0}$ & $\mathbf{2 1 - 3 0}$ & $\mathbf{3 1 - 4 0}$ & $\mathbf{4 1 - 5 0}$ & $\mathbf{5 1 +}$ & Total \\
\hline Married & $13(10 \%)$ & $46(36 \%)$ & $38(29 \%)$ & $22(17 \%)$ & $10(8 \%)$ & $129(92 \%)$ \\
\hline Unmarried & $6(54 \%)$ & $3(28 \%)$ & $2(18 \%)$ & 0 & 0 & $11(8 \%)$ \\
\hline
\end{tabular}

As for as marital status was concerned, 129/140 (92 \%) were married and 11/140 (8\%) were unmarried. Age wise marital distribution shows that in the first age group of 1120years, 13/19 women were married while 6/19 were unmarried. In the second age group of 20-30 years, majority of the women were married showing a percentage of 35 . Only $3 / 49$ were unmarried. In the third age group of $31-40$ years only $2 / 40(5 \%)$ were unmarried. All women above the age of 40 were married. It is interesting to note that the practice of early marriages exist in Pukhtun society so the lower age limit of 11 years is included as an indicator of early age. 
Table 3

Level of Education

\begin{tabular}{|c|c|c|c|c|c|c|c|c|}
\hline $\begin{array}{c}\text { Level of } \\
\text { education }\end{array}$ & $\begin{array}{c}\text { No } \\
\text { education }\end{array}$ & Prim & Middle & Matric & Inter & BA/BSC & MA/M.sc & Total \\
\hline Frequency & $\begin{array}{c}99 \\
(70.7 \%))\end{array}$ & $\begin{array}{c}10 \\
(7.1 \%)\end{array}$ & $\begin{array}{c}3 \\
(2.1 \%)\end{array}$ & $\begin{array}{c}7 \\
(5 \%)\end{array}$ & $\begin{array}{c}7 \\
(5 \%)\end{array}$ & $\begin{array}{c}6 \\
(4.2 \%)\end{array}$ & $\begin{array}{c}8 \\
(5.7 \%)\end{array}$ & $\begin{array}{c}140 \\
(100 \%)\end{array}$ \\
\hline
\end{tabular}

The female literacy rate among women in Pakistan is as low as $45 \%$ (Economic Survey of Pakistan, 2011-12, p, 145) This study explored out that the literacy rate among women in Khyber Pukhtun Khwa (KPK) was $29.3 \%$, much lower than the national figures. The figures from the field showed that out of 140 female respondents 99/140 (70.7\%) were illiterate and only 41/140 (29.3\%) were literate.

$10 / 41$ of the total respondents $(7.1 \%)$ were educated up to primary level, a level of education which does not qualify one for any white collar job even a peon in an office. So this category is well counted in the illiterate category. Again the standard of education in Pakistan is so poor that a primary level educated person cannot write even his name or read a passage from a book or newspaper.

$3 / 140(2.1 \%)$ were educated up to middle level, $7 / 140(5 \%)$ were educated up to matric level and a similar number was educated up to intermediate level. 6/140 (6.2\%) were graduates and 8/140 (5.7\%)were educated up to Master level.

Table 4

Family Size

\begin{tabular}{|l|c|c|c|c|c|c|}
\hline Family Size & $\mathbf{2 - 5}$ & $\mathbf{6 - 9}$ & $\mathbf{1 0 - 1 3}$ & $\mathbf{1 4 - 1 7}$ & $\mathbf{1 8}+$ & Total \\
\hline Frequency & $21(15 \%)$ & $74(52.9 \%)$ & $30(21.5 \%)$ & $11(7.8 \%)$ & $4(2.8 \%)$ & $140(100 \%)$ \\
\hline
\end{tabular}

Average family size $=8.8$

Table 4 shows that $21 / 140$ respondents $(15 \%)$ had $2-5$ members in their families. $74 / 140$ (52.6\%) had a family size of 6-9 persons.30/140 (21.4\%) respondents had 10-13 family members. In the next group 11/140 families had a family size of 14-17 . Only 4/ 140 $(2.8 \%)$ had a family size of $18+$. This gives us an average size of family as 8.8 persons. According to official statistics the average size of family in Pakistan is 7.4 persons. This shows the trend of joint families or more children within nuclear families is in vogue in the research area.

Table 5

Family Income

\begin{tabular}{|c|c|c|c|c|c|c|c|}
\hline $\begin{array}{c}\text { Family } \\
\text { income } \\
\text { (monthly Rs.) }\end{array}$ & $\begin{array}{c}\mathbf{1 , 0 0 0 -} \\
\mathbf{1 0 , 0 0 0}\end{array}$ & $\begin{array}{c}\mathbf{1 1 , 0 0 0 -} \\
\mathbf{2 0 , 0 0 0}\end{array}$ & $\begin{array}{c}\mathbf{2 1 , 0 0 -} \\
\mathbf{3 0 , 0 0 0}\end{array}$ & $\begin{array}{c}\mathbf{3 1 , 0 0 1 -} \\
\mathbf{4 0 , 0 0 0}\end{array}$ & $\begin{array}{c}\mathbf{4 1 , 0 0 0 -} \\
\mathbf{5 0 , 0 0 0}\end{array}$ & $\mathbf{5 1 , 0 0 0 +}$ & Total \\
\hline Frequency & $63(45 \%)$ & $35(25 \%)$ & $19(13.6 \%)$ & $8(5.8 \%)$ & $6(4.3 \%)$ & $9(6.4 \%)$ & 140 \\
\hline
\end{tabular}


Average Family income = Rs. 16,857/- (US \$175.6/per month). Average per capita Income = Rs. 1915/- (US \$ 19.9) per month.

Table 5 shows the income of the families. 63/140 (45\%) families were in the lowest income group of 1000-10,000 rupees per month( US\$ 104)followed by 35/140 (25\%) in the second income group. $13.6 \%(19 / 140)$ respondents had a family income of Rs. Up to 30,000 a month. 5.8\% (8/140), 4.3\% (6/140, and 6.4\% (9/140) families had monthly income of Rupees up to 40,000, 50,000 and ,over 50,000 respectively.

The table shows a consistent decline in the higher income groups. The table gives an average monthly income of each family as 16,857/ (US \$ 175.6) which shows as per month /capita income as low as income of rupees 1915/-(US \$ 19.9)

Table 6

Marital Status and Health of Respondents

\begin{tabular}{|l|c|c|c|}
\hline \multirow{2}{*}{ Marital Status } & \multicolumn{2}{|c|}{ Health Condition } & \multirow{2}{*}{ Total } \\
\cline { 2 - 3 } & Good & Not Good & \\
\hline Married & $8(6.3 \%)$ & $121(93.7 \%)$ & $129(92.2)$ \\
\hline Un-Married & $2(18.2 \%)$ & $9(81.8 \%)$ & $11(7.8 \%)$ \\
\hline Total & $10(7.1 \%)$ & $130(92.8 \%)$ & $140(100 \%)$ \\
\hline
\end{tabular}

Table-VI shows that 121/140 (92.1\%) respondents were married while 11/140 (7.9\%) respondents were unmarried. Regarding health conditions 121/140 (86.4\%) married women reported that their health conditions were not good and only 8/140 (5.7\%) reported that their health conditions were good. This was probably due to the fact that they had visited the hospital for the first time.

The health conditions of the unmarried women were also not good as9/11 (81.8\%) reported that. Only $18.2 \%$ unmarried women said that they had a good health, and they visited the hospital as attendants.

Table 7

Nature of Health Problem/ Disease Pattern

\begin{tabular}{|l|c|c|c|c|c|c|c|c|c|c|}
\hline $\begin{array}{l}\text { Nature of } \\
\text { health problem }\end{array}$ & Med. & Gynae. & Surg. & Ortho. & Dental & Opth & Neuro. & ENT & Cardio & Total \\
\hline Frequency & 82 & 20 & 8 & 3 & --- & 3 & 4 & 2 & 8 & 130 \\
& $(63.0 \%)$ & $(15.4 \%)$ & $(6.2 \%)$ & $(2.3 \%)$ & & $(2.3 \%)$ & $(3.0 \%)$ & $(1.5 \%)$ & $(6.1 \%)$ & $(100 \%)$ \\
\hline
\end{tabular}

Table 7 gives a bird eye view of the nature of the health problems of women. Out of 130 women who had no better health during the last one year, over $63 \%$ women suffered from medical problems. These problems included physical weakness, body aches, anemia, mostly psycho-somatic problem, headache, abdominal problems, gastritis, stomach problems, fever of many types, hypertension, diabetes, and so on. 20/130 (15.4\%) 
women had gynecological problems, 8/130 (6.2\%) respondents had surgical problems. They either needed operations or had post operation complications. 3/130 (2.3\%) respondents had orthopedic problems including sciatica, osteoporosis, arthritis, broken/fractured bone and other chiropody problems.3/130 (2.3\%)respondents had Ophthalmological problems, 4/130 (3.0\%) had neurological disorders, 2/130 (1.5\%) had ENT problems and 8/130 (6.1\%) respondents had cardiac/ heart problems.

The disease pattern shows medical problems as the common health problem while Gynae problems were the second big problem for women.

Table 8

Type/Mode of Treatment

\begin{tabular}{|c|c|c|c|c|c|c|c|}
\hline $\begin{array}{c}\text { Type of } \\
\text { Treatment }\end{array}$ & Shrine & Spiritual & $\begin{array}{c}\text { Home } \\
\text { Treatment }\end{array}$ & $\begin{array}{c}\text { Local } \\
\text { practitioner. }\end{array}$ & $\begin{array}{c}\text { Pub. } \\
\text { Health } \\
\text { Facility }\end{array}$ & $\begin{array}{c}\text { Private } \\
\text { Qualified } \\
\text { Doctors/ } \\
\text { Hakeem }\end{array}$ & Total \\
\hline Frequency & $\begin{array}{c}8 \\
(6.2 \%)\end{array}$ & 10 & $12(9.2 \%)$ & $28(21.5 \%)$ & 25 & 47 & 130 \\
$(7.7 \%)$ & & & $(19.2 \%)$ & $(36.2 \%)$ & $(100 \%)$ \\
\hline
\end{tabular}

Table VIII shows the mode of treatment by the sick women. It is a common practice that poor and those who cannot access/afford the health delivery system, opt for alternate means of treatment including spiritual healing like going to shrines and local priests for treatment. The poorer a society is, greater will be the hold of such belief system, greater the illiteracy in a society is, greater will be the frequency of such non-medical practices and KPK is not an exception rather a good example. In this study it was found that $6.2 \%$ (8/130)women respondent practiced the non-medical means of healing and attended to some shrines in the belief that a dead saint will help her recover from her health problem though according to some sects, Islam prohibits such practices.

$7.7 \%$ (10/130) women resorted to spiritual treatment called Dam Darud, by going to a Mullah (a Muslim who is normally a teacher in a religious seminary, a scholar and leads the prayers). The mullahs who are authorized by his teachers to spell specific verses of the Holy Quran on the sick person and give amulets (a small object consists of some holy wording on a paper or bark of a tree, wrapped in a cloth of white or green color and wear around the neck or tied on the arm in the belief that it will bring good luck and protects the person from evil, injury or sickness).

$9.2 \%(12 / 130)$ women tried medication at home including use of local herbs, analgesic from the corner shops etc. Many times women are put off by men and just bring them medicines like analgesic or tranquilizers so that a woman is let to believe that she is being treated. 
$21.5 \%$ (28/130) respondents got treatment from local practitioner, mostly Para-medics who run successful practices in the rural areas. As they are easily available and are cheaper than the qualified doctors etc. they are approached with more confidence. These practitioners are either homeopaths or allopath or practice both systems at a time. As homeopathic medicines are cheaper, they prescribe them for poor patients .Mostly these practitioners are practiced by virtue of their family background as a person in the family was a doctor/ hakeem (Herbal doctor) and the profession is inherited from generation to generation. 19.2\%(25/130) went to Hospital/Basic Health Units or Rural Health Centers (RHCs) where qualified doctors are employed but seldom available in the facility and who do their practice in the rural areas even in duty hours and the health institution is run by the lower staff like dispensers, LHVs (Lady health Visitors) or even the orderlies and security guards.

$36.2 \%(47 / 130)$ respondents visited a qualified (MBBS) doctor or Unani Hakeem (Greek Herbal doctors who practice Greek pharmacopeia) and run his/her private clinic in the local areas and have been a very trusted healing system for the last many centuries and which is still trusted by many.

Table 9

Sex of the Health Care Expert Attended

\begin{tabular}{|l|c|c|c|}
\hline $\begin{array}{l}\text { Sex of the Doctor } \\
\text { Attended }\end{array}$ & Male & Female & Total \\
\hline Frequency & $81(73 . \%)$ & $30(27 \%)$ & $111(100 \%)$ \\
\hline
\end{tabular}

$81 / 111(73 \%)$ women attended to male health practitioners while only $27 \%$ went to a female health worker. This is the main drawback of the health delivery system as women are conditioned to go to male doctors even if they have women-specific problems. This is the main drawback of the health delivery system as women are conditioned to go to violate the cultural barriers.

Cultural barrier here means that most women observe purda (veiling the face and body) and also not to talk to any person other than a family member which in this context means they cannot openly discuss their feminine health problems with male practitioners. On the other hand the drawback of the health delivery system is that very few female qualified doctors are available in the rural area. Not only qualified female doctors, even female Paramedics like LHVs, nurses, female medical technicians etc. are not available. As a result, no comprehension of the health problems of women is made by male doctors etc. The table shows that a vast majority of $72.9 \%(81 / 111)$ females was conditioned to visit male doctors while 30/111 (27.02\%) respondents visited female doctors. This is a cultural issue and needs anthropological studies for a just solution. 
Table 10

Cost of Treatment

\begin{tabular}{|c|c|c|c|c|c|c|}
\hline $\begin{array}{c}\text { How Much it } \\
\text { Cost you (rupees) }\end{array}$ & \multicolumn{2}{|c|}{ First Time } & \multicolumn{2}{c|}{ Second Time } & \multicolumn{2}{c|}{ Third Time } \\
\cline { 2 - 7 } & Freq & Percent & Frequency & Percent & Frequency & Percent \\
\hline $\mathbf{1 , 0 0 0 - 5 , 0 0 0}$ & 92 & $83 \%$ & 44 & $69.9 \%$ & 32 & $74.4 \%$ \\
\hline $\mathbf{5 0 0 1 - 1 0 0 0 0}$ & 9 & $8 \%$ & 8 & $12.7 \%$ & 7 & $16.4 \%$ \\
\hline $\mathbf{1 0 0 0 1 - 1 5 0 0 0}$ & 1 & $0.90 \%$ & 4 & $6.3 \%$ & 2 & $4.6 \%$ \\
\hline $\mathbf{1 5 0 0 1 - 2 0 0 0 0}$ & 4 & $3.60 \%$ & 4 & $6.3 \%$ & 2 & $4.6 \%$ \\
\hline $\mathbf{2 0 0 0 1 - 2 5 0 0 0}$ & 1 & $0.90 \%$ & 3 & $4.8 \%$ & -- & -- \\
\hline Above 25000 & 4 & $3.60 \%$ & --- & --- & --- & -- \\
\hline Total & $\mathbf{1 1 1}$ & $\mathbf{1 0 0} \%$ & $\mathbf{6 3}$ & $\mathbf{1 0 0 . 0} \%$ & $\mathbf{4 3}$ & $\mathbf{1 0 0 . 0} \%$ \\
\hline
\end{tabular}

Average cost of treatment $=$ Rs. $5459 /=$

Table 10 shows the amount of money spent on treatment for the first, second and third time. Table shows that for the first time 111/140 patients attended to a health facility. Out of 111 patients only 63 turned up again for treatment and the remaining 48/111 got successful treatment. On the third occasion only $43 / 111$ patients visited the health facility.

In the first instance $92 / 111(83 \%)$ women patients spent up to 5,000/- rupees. In the same category $9 / 111(8 \%)$ spent up to 10,000 on their health and $4 / 111(3.60 \%)$ women spent up to 20,000 rupees on themselves, and 4/111(3.60\%) spent over 25,000 rupees on health maintenance. $1 / 111$ (less than $1 \%$ ) women spent up to 15,000 and 25,000 respectively on their health. This gave an average expenditure of rupees 5031/- by each women on their first experience of health problem.

On the second occasion there were 63/111 women who attended to the facility for assistance. Among them 44/63 (69\%) spent up to 5,000 rupees on their health, 8/63 $(12.7 \%)$ spent up to 10,000 on their health, $4 / 63(6.3 \%)$ each spent up to 15,000 and 20,000 rupees respectively. $3 / 63(4.8 \%)$ spent rupees 25,000 on health. The average expenditures/ woman on health for the second time were Rs. 6776/.

On the third visit there were only $43 / 111$ women. Out of this number $32(74.4 \%)$ spent up to $5,000 /$ - rupees each, $7 / 43(16.4 \%)$ spent a sum of Rs. 10,000/- each. $2 / 43(4.6 \%)$ each in the last two groups spent Rs.20,000 and 25,000 rupees each. This gave an average expenditures of Rs. 4848 by every patient.

The overall average expenditures for the entire health crisis and the three visit cost a sum of Rs. 5459/- each woman. 
This is the amount spent directly on the purchase of medicines, transportation, consultation fees, laboratory test etc and did not include the daily wages/ earning of the person (husband/ father, father-in-law, brother-in-law) who escorted the women to the hospital.

This is now a balance sheet of income and expenditures. Look back at table -3 on income of the family. We know that per capita income in the area was 1915 rupees or a bit over $16000 /-$ per family. If on one person the family spends Rs.5, 000, what would be the economic condition of the family particularly the expenditures on food. Obviously, the family will have to cut the stomach and divert resources to save a member of the family. Consequently malnutrition will be the fate of the family. This shows the utter helplessness of the poor people and their dilemma. If they don't spend on health, death is there, if spend on health hunger is there. This is the point on which we hypothesized that the poorer a province, poorer will be the health condition even if facilities are available but how to access them. This is a problem of availability structure and opportunity structure. Opportunity is there but availing it is a problem.

Table 11

Who Decided your Visit to the Hospital for Treatment?

\begin{tabular}{|l|c|c|c|c|c|c|c|c|c|c|}
\hline $\begin{array}{l}\text { Decision } \\
\text { maker }\end{array}$ & Own self & husband & mother & $\begin{array}{c}\text { Mother- } \\
\text { in-law }\end{array}$ & father & $\begin{array}{c}\text { Father-in- } \\
\text { law }\end{array}$ & sister & $\begin{array}{c}\text { Sister- } \\
\text { in-law }\end{array}$ & others & Total \\
\hline Freq. & $\begin{array}{c}15 \\
(13.52 \%)\end{array}$ & $\begin{array}{c}56 \\
(50.46 \%)\end{array}$ & $\begin{array}{c}5 \\
(4,50 \%)\end{array}$ & $\begin{array}{c}9 \\
(8.10 \%)\end{array}$ & $\begin{array}{c}10 \\
(9.00 \%)\end{array}$ & $\begin{array}{c}13 \\
(11.72 \%)\end{array}$ & $\begin{array}{c}1 \\
(0.9 \%)\end{array}$ & $\begin{array}{c}1 \\
(0.9 \%)\end{array}$ & $\begin{array}{c}1 \\
(0.9 \%)\end{array}$ & $\begin{array}{c}111 \\
(100 \%)\end{array}$ \\
\hline
\end{tabular}

Pukhtun society is patrilineal, patriarchal, and patrilocal. Patriarchy means dominance of the male in all decision in a family including decision regarding the conduct of behavior of women.

Culturally, a woman cannot go out of the home environment without being escorted. In some cases there are exceptions like a woman above the age of 50 years or too poor a women accompanied by a minor girl or a female from the village / neighborhood or people living in the close vicinity of the health facility etc. Still permission of the male head of the family is must $\backslash$ irrespective of the fact whosoever accompany the woman to the hospital.

In the table $11,15 / 111(13.52 \%)$ women who decided of their own to attend to a health facility, may belong to the above mentioned category of women otherwise under normal conditions a woman must be accompanied by a member of the family preferably a man. The most preferred way is to seek permission of the husband for going to a hospital. In this case 56/111 (50.46\%) respondents said that their husbands made the decision to send them for treatment, 5/111(4.50\%) respondents mothers sent them for treatment, $9 / 111(8.10 \%)$ respondents mother in laws sent them for treatment, $10 / 111(9.00 \%)$ 
respondents fathers sent them for treatment, $13 / 111(11.71 \%)$ respondents father in law sent them for treatment, $1 / 111(0.90 \%)$ respondents sister sent them for treatment, $1 / 111(0.90 \%)$ respondents sister in law sent them for treatment while $1 / 111$ $(0.90 \%)$ respondents said that other people i.e. brothers etc were involved in making the decision to sent them for treatment.

The male domination in decision making even about the health problems of women is clear from the table. In $62 \%$ cases it is the male who decide whether a women can attend a hospital or not. (Objective-1)

Table 12

Place of Delivery\& who Assisted you

\begin{tabular}{|l|c|c|c|c|c|}
\hline \multirow{2}{*}{$\begin{array}{c}\text { Place of } \\
\text { Delivery }\end{array}$} & \multirow{2}{*}{ F } & \multicolumn{3}{|c|}{ Who attended } & \multirow{2}{*}{ Total } \\
\cline { 3 - 5 } & Doctor & $\begin{array}{c}\text { Nurse/ } \\
\text { mid-Wife/LHV }\end{array}$ & $\begin{array}{c}\text { TBA/ Mother- } \\
\text { in law }\end{array}$ & \\
\hline Home & $98(76 \%)$ & 0 & $20(20 \%)$ & $78(80 \%)$ & $98(76 \%)$ \\
\hline Hospital & $31(24 \%)$ & 31 & ---- & --- & $31(24 \%)$ \\
\hline Total & $129(100 \%)$ & 31 & $20(20 \%)$ & $78(80 \%)$ & $129(100 \%)$ \\
\hline
\end{tabular}

More than $80 \%$ women delivered the baby at home in the presence of unskilled birth attendants. In majority of secondary and tertiary health care centers, emergency obstetrical care is not available on 24 hours basis.

A child birth or delivery at home causes many complications for the health of the mother due to many reasons. This fact is being reported by many observers and health experts. Some of the major complications are the spread of Hepatitis C Virus (HCV), Hepatitis B Case (HBC), excessive bleeding during and after delivery leading to maternal deaths, and a number of other complications. The main reason is that $76 \%$ deliveries take place at home attended by the traditional birth attendants' (TBAs), who are either mother -inlaws or an experienced woman in the village / surrounding famous for helping at such times. Normally, these women are unaware of the many infections due to unhygienic conditions; they carry with them to the woman. But the reason is that it is easy, cheap and is considered 'respected' by the family. On the other hand, delivery at proper clinics, this may be safe but cost a lot of money running in thousands.

The recent trend is that an LHV / Mid-wife is called to the place of delivery but is also an expensive matter and normally costs up to five thousand rupees as fee. In addition to the fee to the concerned Mid-wife/ LHV, if the new born is a boy, theses health providers demands for extra gratifications like gifts etc. In $20 \%$ cases such health experts were called to the homes. 
Table 16 shows that 98/129respondents children were born at home. 24\% (31/129) respondents delivered the baby at hospital. These were the people who were either told in advance about some expected complications during pregnancy or who could afford the cost (objective-2).

Table 13

Purchase of Prescribed Medicines

\begin{tabular}{|l|c|c|c|}
\hline $\begin{array}{l}\text { Could you purchase the prescribed } \\
\text { medicines }\end{array}$ & Yes & No & Total \\
\hline Frequency & $69(49.29 \%)$ & $71(50.71 \%)$ & $140(100 \%)$ \\
\hline
\end{tabular}

Poverty is the main cause of diseases and diseases are the main cause of poverty. This table shows many patients could not afford to purchase the required medicines due to their poor economic conditions. We hypothesized that poorer an area, poor will be the health of the people. This indicator of not availing medicines is a sign of extreme poverty.

Table 13 shows that $69 / 140(49.29 \%)$ respondents said it that they got a prescription but they didn't buy that while $71 / 140(50.7 \%)$ said that they bought whatever was prescribed.

Table 14

Satisfaction with the Available Health Facilities

\begin{tabular}{|l|c|c|c|}
\hline $\begin{array}{l}\text { Satisfaction with the health } \\
\text { facilities }\end{array}$ & Yes & No & Total \\
\hline Frequency & $62(44.3 \%)$ & $78(55.7 \%)$ & $140(100 \%)$ \\
\hline
\end{tabular}

Table 19 shows that $62 / 140(44.3 \%)$ respondents were satisfied with the health facilities available in their area while 78/140 (55.7\%) respondents were not satisfied with the health facilities available in their area. The non-satisfaction was mainly due to nonavailability of free medicines in the health facilities, non-availability of female doctors and Para-medical staff, harsh attitude of the doctors and other staff, nepotism, no attention to poor people, poverty of the patients, long distances, high cost of treatment etc.

\section{Discussion}

Pakistan is politically and economically a developing country with many of the socioeconomic indicators below the minimum possible standard even in the region. Poverty is the main problem fueled by massive corruption and embezzlement by those at the helms of affairs. Loan sharking and transferring national wealth into personal off-shore accounts is an order of the day. Even laws are mulled to give impunity to those who are in a position to amass immoral fortune. Bureaucracy is strong and national institutions are weak. Disorganization, lawlessness, terrorism, are some of the immediate problems 
confronting ordinary Pakistani. Education is in shambles with the maximum possible level of illiteracy and low quality of education and so on.

When we talk of the weak institutions, health is not an exception as it is directly governed by the state or the political institution. Problems of health in general and women health problems in particular are numerous and multi-faceted imbedded in the cultural system and economy of the people. Children preventable-health problems leading to child and infant mortality, women health problems leading to maternal mortality are the most burning issues of the health delivery system. As this article is about the rural health problems, the discussion is confined to the topic.

National poverty in general and women's economic poverty in particular is of great concern. Women are supposed to confine to 'four-walls' and hence are poor, both economically and socially. Women are socially poor as well as they are of secondary status culturally. Even they cannot decide to attend to a doctor or health facility of their own choice. Poverty is so rampant that in many cases women could not purchase the prescribed medicines. Expenditures on health are greater than the income of the family leading to a cut in the food items and hence under nourishment and perpetuation of poverty and a mass dissatisfaction with the health delivery system.

Culturally, they depend upon the choice of the Mother-in-law and other in-laws. Her visit to a hospital or doctor is decided by them. This is because of the traditional jealousy and mistrust between the mother-in-law and daughter-in-law, a characteristic of the joint family system.

Child births take place, mostly, at home in the hands of the Traditional Birth Attendants (TBAs) or mother in-law causing many complications in the post-natal stage and many times the infections lead to maternal mortality. Taking a woman to a female health facility or hospital for delivery of a child also depends upon the financial position of the family as well as choice of the mother-in-law.

In such cases women are deliberately kept away from hospitals and put-off with selfmedication at home or asked to go for alternate methods of treatment like visiting a shrine or spiritual healing or traditional Greek medication System/ herbal medical practitioner known as Unani Hakeems with the minimum possible chances of health improvement. The disease pattern clearly shows that the major health problems of women were either medical (a broad term including many diseases of psycho-somatic nature) or gynecological.

The problem is fuelled by the state apathy and lack of will and power to redress the problem. On the face of an Islamic ideological country where residents are mostly 
Muslims and the religion has a pervasive impact on the people. Observing Purdha seclusion of women has deep cultural and religious meaning but the state violates the religious and cultural ethics by conditioning women to attend to a male doctor even in serious female-specific health problems. Not only this in many areas there is no womenspecific health delivery system and if there is one, is of no use to the needy due to nonavailability of medics and medicines.

\section{Conclusions}

Health delivery system in rural Pakistan is confronted with many problems. Poverty is the main cause fuelled by massive corruption and embezzlement on state level leaving less or nothing for investment in the health system. Women are particularly poor because of the culture of poverty. Centuries old method of child birth and visits to shrine for treatment are still practiced resulting in worsening of women health. Lack of will and power and gender discrimination on the State level has aggravated the situation.

\section{References}

Gilbert, N. (1993). Researching Social Life. London: Sage Publication, p,125

Government of NWFP (2008). Important District-Wise Socio-economic Indicators, 2007. Peshawar : Bureau Of Statistics, Planning and Development department. P, iv.

Government of NWFP (2009). Important District-wise Socio-EconomicIndicators-2008. Peshawar: Bureau of Statistics, Planning and Development Department, P, vi.

Government of Pakistan (2008). Pakistan in Figures2008. Islamabad: Federal Bureau of Revenue, $\mathrm{p}, 145$.

Government of Pakistan (2009). Social Statistics . Islamabad: Federal Bureau of Statistics, $\mathrm{p}, 1$.

Government of Pakistan (2009). Socio-Economic Survey of Pakistan -2008-9. Islamabad: Federal Bureau of Revenue, p, 169.

Government of Pakistan (2011). Economic Survey of Pakistan -2011-12. Islamabad: Federal Bureau of statistics.

Mehbub ul Haq Human Development Centre (MHHDC) (2009). Human Development in South Asia2007: A Ten Year Review. Oxford University Press, New York, p, 209 
Society of Obstetricians \& Gynecologists of Pakistan (2009).Health of Women in Pakistan: Annual Report 2009, Karachi, p, 3

Dr. Amir Zada Asad is Professor in the Department of Social Work, Peshawar University. Sumera Farid is Lecturer in the Department of Social Work, Peshawar University.

Dr. Basharat Hussain is Assistant Professor in the Department of Social Work, Peshawar University. 